\title{
Supply Chain Risk Management within the Context of COSO's Enterprise Risk Management Framework
}

\author{
Thomas V. Scannell ${ }^{1}$, Sime Curkovic ${ }^{1}$, Bret J. Wagner ${ }^{1} \&$ Michael J. Vitek $^{2}$ \\ ${ }^{1}$ Haworth College of Business, Western Michigan University, Kalamazoo, MI, United States \\ ${ }^{2}$ Mercedes-Benz Technology, Troy, MI, United States \\ Correspondence: Thomas V. Scannell, Haworth College of Business, Management Department, Western Michigan \\ University, Kalamazoo, MI, 49008, United States. Tel: 1-269-387.5419, E-mail: Thomas.scannell@wmich.edu
}

Received: December 30, 2012

Accepted: January 17, $2013 \quad$ Online Published: January 21, 2013

doi:10.5430/jbar.v2n1p15

URL: http://dx.doi.org/10.5430/jbar.v2n1p15

\begin{abstract}
This study examined how companies identify and manage supply chain risks and how those actions relate to systemic enterprise risk management (ERM). The structure, implementation, and maintenance of supply chain risk management (SCRM) systems and tools are described, and the potential integration of SCRM with ERM is explored. The ERM framework proposed by The Committee of Sponsoring Organizations (COSO) of the Treadway Commission (COSO, 2004) is used to examine such integration. Data from 46 firms were analyzed to identify which factors affect the decision to develop an SCRM system and how the resultant systems compare to an ERM system. It is suggested that explicitly linking SCRM with ERM will more readily advance research regarding these important issues and support supply managers in their efforts to develop SCRM strategies, garner the necessary resources, and execute SCRM at their firms.
\end{abstract}

Keywords: Supply, Supply chain risk Management (SCRM), Enterprise risk management (ERM), COSO

\section{Introduction}

Every firm is engaged in some type of risk management. However, few firms conduct risk management using a systematic approach (Beasley et al., 2005; Bowling \& Rieger, 2005). Enterprise risk management (ERM), though not widely adopted, provides a framework and set of tools for managing risks holistically. ERM has been defined a variety of ways, bust most definitions focus on holistically identifying, assessing and managing risks throughout an organization and its value chain (COSO, 2004).

Supply chain risk management (SCRM), one element of ERM, is emerging as a viable, proactive, and strategic supply chain management (SCM) application. However, existing SCRM models do not explicitly make the linkage to ERM. This research focuses on the structure, implementation, and maintenance of a formal SCRM system and how such a system may be integrated with ERM. The ERM framework proposed by The Committee of Sponsoring Organizations (COSO) of the Treadway Commission (COSO, 2004) is used to examine such integration. It is suggested that explicitly linking SCRM with ERM may more readily advance research regarding these important issues and support supply managers in their efforts to develop SCRM strategies, garner the necessary resources, and execute SCRM at their firms.

Data from 46 firms were analyzed to identify which factors affect the decision to develop an SCRM system and how these factors can influence the level of ERM and SCRM success. The decision to manage supply chain risks constitutes a major undertaking for most firms. Such an undertaking is a response to a number of factors or influences. There seems to be recognition that succeeding requires more than simply creating a new program or department. It is suggested that various factors act to pre-condition the firm and its systems to the introduction, acceptance, and progress on managing supply risks.

The remainder of this paper begins with a review of the literature, followed by the methods section. The survey data are then analyzed to profile the respondents and identify how they manage supply chain risks. The article then concludes with an evaluation of the factors underlying the decision to develop a system for managing supply chain risks and how these factors can be leveraged into a competitive advantage through ERM. 


\section{Literature Review}

The literature review consists of four related sections. First, the rationale for pursuing a standard risk framework is presented. Next, an established ERM framework is explored. Proposed SCRM frameworks are then discussed relative to the ERM framework. Finally, an overview of supply risks and approaches that were included in the survey is presented.

\subsection{Rationale for a Standard Framework}

The advancement of research in a discipline (e.g., Just-In-Time Manufacturing, Supply Chain Management) may be accelerated through the development and validation of frameworks and concepts generated through exploratory empirical research. For example, the Total Quality Management (TQM) discipline leveraged standardized frameworks to advance theory building and testing [see for example (Black \& Porter, 1996; Capon et al., 1994; Curkovic et al., 2000; Dean \& Bowen, 1994; Flynn et al., 1994; Saraph et al., 1989)]. By leveraging such frameworks, TQM research moved from a focus on case studies (the current state of SCRM research) to testable models and specific research hypotheses, linking the theoretical concept of TQM to empirical indicants. Operational definitions and standardized frameworks have contributed to TQM theory building by identifying the constructs associated with TQM, developing scales for measuring these constructs, and empirically validating the scales. SCRM research is still in its infancy stages and would benefit from development of standardized frameworks and concepts.

Sodhi, Son and Tang (2012) identified the lack of consensus regarding the scope of SCRM as a critical gap in SCRM research. They suggested that there is a great need to reach a consensus on such issues in order to better communicate with company executives and practitioners, and to more quickly advance SCRM research. They also suggest that SCRM is a subset or extension of ERM (Sodhi et al., 2012). Given their suggestions, the COSO ERM framework was identified as a potential consensus framework for SCRM that could fill the research gap while also contributing to managerial efforts to link SCRM to corporate-wide risk management efforts.

\subsection{Enterprise Risk Management and the COSO Framework}

Global competitive landscapes and increasingly complex supply chain processes and partnerships, coupled with increased requirements to comply with regulations, laws and industry guidelines has heightened awareness that firms may benefit from a systematic approach to risk management. Enterprise risk management (ERM) has garnered significant academic, consultant and practitioner interest over the last decade as a way to not only mitigate risk but to take advantage of risk opportunities (Hoyt \& Liebenberg, 2011; Nocco \& Stulz, 2006). ERM is a process for identifying, analyzing and proactively planning responses to a portfolio of risks (Bowling \& Rieger, 2005; Chapman, 2003).

Though effective ERM can provide significant benefits for a firm (Hoyt \& Liebenberg, 2011; Smithson \& Simkins, 2005), a relatively small percentage of firms have a detailed understanding of this integrated process and adoption of ERM is rather limited (Chapman, 2003; COSO, 2010). Ad hoc approaches to risk management by various "silos" in an organization leads to duplication of resources, uncoordinated planning and less efficient and effective risk management processes (Hoyt \& Liebenberg, 2011).

Varying frameworks have been proposed to support and standardize implementation of systematic ERM. Sample frameworks include the Joint Australia/New Zealand AS/NZ 4360-2004, the Turnbull Guidance, and the ISO standards for risk management. This research adopts the framework developed by The Committee of Sponsoring Organizations (COSO) of the Treadway Commission (COSO, 2004), shown in Figure 1. This framework perhaps the most widely discussed and familiar ERM framework (COSO, 2010). COSO is a voluntary private sector organization, led by the Institute of Management Accountants, The Institute of Internal Auditors Inc., Financial Executives International, the American Accounting Association, and the American Institute of Public Accountants. COSO provides executive management with guidance regarding effective, efficient and ethical business practices.

The COSO ERM framework consists of eight components of ERM that are needed to help a firm achieve its objectives, as described in Table 1 (COSO, 2004; Sobel, 2006). All eight components need to be implemented and integrated to provide effective ERM. The framework also emphasizes entity wide risk management across four objectives: strategic, operations, reporting, compliance. The COSO framework also emphasizes that risks are examined at each level of the organization (i.e., subsidiary, business units, division, entity) beginning with the entity level and aggregated across all levels so that a portfolio of risks can be managed holistically (Chapman, 2003; COSO, 2004). This research focuses on the "entity" level and "operational" objectives across the eight components of ERM. 


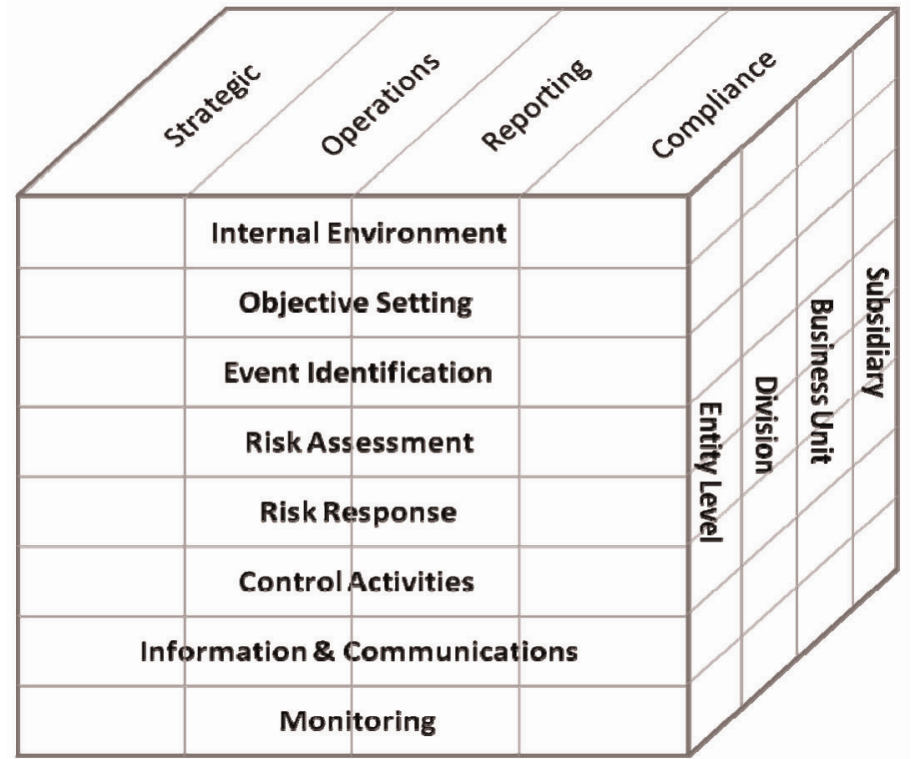

Figure 1. COSO ERM framework

Table 1. Interrelated components of the COSO ERM framework

\begin{tabular}{|c|c|}
\hline Component & Description \\
\hline $\begin{array}{l}\text { Internal } \\
\text { Environment }\end{array}$ & $\begin{array}{l}\text { Reflects alignment of the firm's risk philosophy, its appetite for risk, the risk management and } \\
\text { ethical culture, human resource policies and practices, assignment of responsibility, and the } \\
\text { organizational structure to manage risks. }\end{array}$ \\
\hline Objective Setting & $\begin{array}{l}\text { Identifies the firm's competitive strategy or positioning (e.g., low cost, high quality, etc.) and } \\
\text { related objectives in four areas: strategy, operations, reporting and compliance, which in turn } \\
\text { drives objectives throughout the value chain. }\end{array}$ \\
\hline Event Identification & $\begin{array}{l}\text { Identifies possible internal and external events, and the potential interrelatedness of those } \\
\text { events, that impact a firm's ability to realize its strategy and objectives. Positive impact events } \\
\text { are "opportunities" that are channeled back to strategic planning, while negative impact events } \\
\text { are risks that should be managed through an integrated risk management process to help } \\
\text { determine how such risks might be managed. }\end{array}$ \\
\hline Risk Assessment & $\begin{array}{l}\text { Examines the likelihood, frequency and the impact (e.g., financial, reputation, etc.) of events } \\
\text { across a range (e.g., best to worst case) of possible outcomes associated with the events. }\end{array}$ \\
\hline Risk Response & $\begin{array}{l}\text { Identifies, assesses and selects risk response options that align with the organization's risk } \\
\text { tolerances and risk appetite. Options include avoidance (e.g., not engaging in the activity), } \\
\text { reduction (e.g., rebalancing the risk, reallocating resources, robust business process, etc.), } \\
\text { sharing (e.g., insurance, partnering, contractual agreements, hedging, etc.) and acceptance. }\end{array}$ \\
\hline Control Activities & $\begin{array}{l}\text { Establishes that risk policies and procedures are in place and properly executed, and that the } \\
\text { risk management initiatives are effective. Such controls may include required authorizations, } \\
\text { supervision, segregation of duties, reconciliations and verifications for example. }\end{array}$ \\
\hline $\begin{array}{l}\text { Information \& } \\
\text { Communications }\end{array}$ & $\begin{array}{l}\text { Requires that internal and external sources be used to provide appropriate and timely risk } \\
\text { related information that enables people to execute their responsibilities. Such communications } \\
\text { need to be integrated throughout the value chain and impacted organizations. }\end{array}$ \\
\hline Monitoring & $\begin{array}{l}\text { Ensures that an ERM is present and determines how well it is working so that it can be revised } \\
\text { and/or expanded. }\end{array}$ \\
\hline
\end{tabular}


COSO defines risk as the probability that an event may occur which adversely impacts the achievement of objectives (Chapman, 2003). However, given that some risks if managed proactively may lead to positive outcomes for a firm, the framework supports management of positive risk opportunities and negative risk impacts.

COSO formally defines ERM as “...a process, effected by an entity's board of directors, management and other personnel, applied in a strategy setting and across the enterprise, designed to identify potential events that may affect the entity, and manage risks to be within its risk appetite, to provide reasonable assurance regarding the achievement of entity objectives." (COSO, 2004)

ERM and related frameworks are not without detractors. Even COSO states that its ERM framework is not a panacea and is a challenge to implement, and it invites research based on better understanding the framework (Landsittel \& Rittenberg, 2010). There is a lack of empirical research into the effectiveness of ERM in general (Hoyt \& Liebenberg, 2011) and the specific frameworks in particular. Other detractors note that implementing ERM requires a substantial commitment of resources (time, personnel, money) that are not likely to be available during lean times, and a cultural shift of the entire organization (Ballou \& Heitger, 2005) without an appropriate return on such efforts (Samad-Khan, 2005). However, with appropriate planning and execution COSO's ERM framework may be implemented by any organization, from large to small firms (Ballou \& Heitger, 2005; Chapman, 2003; COSO, 2004).

\subsection{Linking ERM and SCRM Frameworks}

SCRM frameworks have also been proposed (Hallikas et al., 2004; Kleindorfer \& Saad, 2005; Manuj \& Mentzer, 2008; Tummala \& Schoenherr, 2011). There are many similarities in these frameworks, though there is no consensus on the scope of SCRM (Sodhi, et al., 2012). In some cases, the concepts are the same, but the terms used are slightly different (e.g., risk assessment versus risk evaluation) and some frameworks do not explicitly identify key processes (e.g., monitoring and review). Table 2 compares four SCRM frameworks with the COSO framework.

Table 2. Comparison of SCRM Frameworks to COSO

\begin{tabular}{|c|c|c|c|c|}
\hline COSO 2004 & $\begin{array}{l}\text { Hallikasa et. al., } \\
2004\end{array}$ & $\begin{array}{l}\text { Kleindorfer \& Saad, } \\
2005\end{array}$ & $\begin{array}{l}\text { Manuj \& Mentzer, } \\
2008\end{array}$ & $\begin{array}{l}\text { Tummala \& } \\
\text { Schoenherr, } \\
2011\end{array}$ \\
\hline \multicolumn{5}{|l|}{ Internal Environment } \\
\hline \multicolumn{5}{|l|}{ Objective Setting } \\
\hline Event Identification & Risk identification & $\begin{array}{l}\text { Specifying sources } \\
\text { of risks and } \\
\text { vulnerabilities }\end{array}$ & Risk Identification & $\begin{array}{l}\text { Risk Identification; } \\
\text { Risk Measurement }\end{array}$ \\
\hline Risk Assessment & Risk assessment & Assessment & $\begin{array}{l}\text { Risk assessment and } \\
\text { evaluation }\end{array}$ & $\begin{array}{l}\text { Risk assessment; } \\
\text { Risk Evaluations }\end{array}$ \\
\hline Risk Response & $\begin{array}{l}\text { Decision and } \\
\text { implementation of } \\
\text { risk management } \\
\text { actions }\end{array}$ & Mitigation & $\begin{array}{l}\text { Selection of } \\
\text { appropriate risk } \\
\text { management } \\
\text { strategies; } \\
\text { Implementation of } \\
\text { supply chain risk } \\
\text { management } \\
\text { strategies; } \\
\text { Mitigation of supply } \\
\text { chain risks }\end{array}$ & $\begin{array}{l}\text { Risk mitigation \& } \\
\text { contingency plans }\end{array}$ \\
\hline \multicolumn{5}{|l|}{ Control Activities } \\
\hline \multicolumn{5}{|l|}{$\begin{array}{l}\text { Information \& } \\
\text { Communications }\end{array}$} \\
\hline Monitoring & Risk monitoring & & & $\begin{array}{l}\text { Risk control \& } \\
\text { monitoring }\end{array}$ \\
\hline
\end{tabular}


Though SCRM frameworks and COSO share many similarities, there are significant differences. Most noticeably, the COSO framework explicitly identifies internal environment, objective setting, control activities and information $\&$ communications as key components of risk management. Some of those components are implied and/or integrated into some of the SCRM frameworks, but the COSO framework provides a more explicit and comprehensive framework. This might be expected as COSO is an "enterprise: framework while the SCRM frameworks are "operational". But that is the point. Until SCRM is positioned as a key component of ERM, supply managers will continue to struggle to secure the resources and to make risk decisions that support corporate wide strategy and objectives, and researchers will struggle to identify and measure risk management factors.

\subsection{Supply Chain Risks and Practices}

Firms face multiple supply risks, whether in combination or isolation. Sample risks include supplier reliability/failure, information errors, natural disasters, shrinkage, capacity shortages, financial instability, currency exchange rate fluctuations, port security and increased government regulations for example (Blackhurst et al., 2005; Kumar \& Verruso, 2008; Liu \& Cruz, 2012; Manuj \& Mentzer, 2008; Tummala \& Schoenherr, 2011; Zsidisin \& Hartley, 2012). Each risk might require a specific SCRM technique (Zsidisin \& Wagner, 2010).

SCRM treatment options include evaluation and trust building (Laeequddin et al., 2009), use of dual sources (Khan \& Burnes, 2007), environmental scanning (Zsidisin et al., 2004), combined capacity reservation contracts and spot markets (Inderfurth \& Kelle, 2011), supply chain modeling and information systems integration (Giannakis \& Louis, 2001), qualification and use of capable suppliers (Manuj \& Mentzer, 2008), supplier quality management initiatives (Holschbach \& Hofmann, 2011), buffer inventory (Tang, 2006), contingency plans (Kleindorfer \& Saad, 2005), credit analysis (Kern et al., 2012), strategic sourcing and flexibility (Chiang et al., 2012), forward buying or hedging (Zsidisin \& Hartley, 2012) and supplier development (Matook et al., 2009) for example. Despite the plethora of risks and risk management approaches, few firms have a structured SCRM approach (Martin et al., 2011).

\section{Research Method}

The purpose of this study was to identify how companies identify and manage supply chain risks and how those actions relate to systemic ERM. The research was exploratory in nature. A purposeful sample was selected to support the research objectives and methodology (Eisenhardt, 1989; Miles \& Huberman, 1994). Key criterion included that the company would agree to identify an informed respondent, reply in a timely manner to a scaled and open ended survey, and be willing to participate in follow-up questions as needed. All targeted companies were known to support supply management educational programs and professional associations.

A total of 67 surveys were sent to perceived supporters of the effort. Several industries were chosen for this study to achieve some level of generalizability. A total of 46 completed responses were received. Early to late respondent survey comparisons were made to analyze potential non-response bias (Armstrong \& Overton, 1977). The mean values for 7 randomly selected questions were compared between the first $25 \%$ of responses and the last $25 \%$ of responses. No statistically significant differences were found between responses. The majority of non-respondents indicated that either company policy prevented them from participation in this particular survey or that resources were constrained when the survey was distributed.

\section{Results}

\subsection{Respondent Profiles}

The majority of responses (84.8\%) were from manufacturing firms (e.g., automotive, electronics, furniture, aerospace, etc.). All companies were based in North America and had global sales. Approximately $60 \%$ of companies were publicly owned, $33 \%$ privately owned and $7 \%$ publicly/privately owned. Companies were asked to have the survey completed by the person most familiar with supply risk management in their organizations. Table 3 suggests that informed respondents replied to the survey.

Table 3. Respondent titles

\begin{tabular}{lc}
\hline Title & Percent \\
\hline Procurement or Supply Chain Leader / Manager / Coordinator & $37 \%$ \\
Supply Chain Director / Vice President & $16 \%$ \\
Materials / Inventory Manager & $16 \%$ \\
Strategic / Senior Buyer & $13 \%$ \\
Plant Manager & $6 \%$ \\
Supply Chain Analyst & $6 \%$ \\
Account / Sales Director & $6 \%$ \\
\hline
\end{tabular}




\subsection{Data Mapped to COSO Framework}

Enterprise and supply chain risk management is a highly integrated process that requires coordination of strategy, process, policy and tools throughout the value chain. Though discussed in separate sections below, each of the categories of the COSO ERM framework should be present and integrated to most effectively manage risks.

\subsubsection{Internal Environment and Objective Setting}

Table 4 provides descriptive statistics related to internal environment and objective setting. All "agree / disagree" questions are scaled from $1=$ strongly disagree to $7=$ strongly agree. All "extent of use" questions are scaled from 1 $=$ not used to $7=$ extensively used.

Need: Respondents clearly believe that risk management is a critically important strategic initiative for their firms and that the management of risk should be a core issue in the planning of any organization. However, the concomitant development of resources, tools and budgets appears lacking as suggested below.

Approach: Managing risks requires an integrated and systemic approach as he COSO framework suggests. Firms recognize that no single set of tools or technologies exist to manage all risks, so despite the clear need there is a significant challenge in implementation. Approximately half the firms agreed that supply chain risks are managed reactively rather than proactively, and that risk initiatives are driven top-down. It appears that in the absence of risk management applications, these firms are building risk considerations into traditional SCM applications (e.g., spend, contract, \& inventory management, demand planning, benchmarking, building long-term partnerships, etc.) on an ad-hoc basis.

Budget: Respondents suggested that firms are spending funds on supply risk management, but few suggested that spending was "very high" (only $26 \%$ of firms agreed that spending was very high.) Budget allocations varied depending on firm size (larger firms having larger budgets) and industry type (service firms spending more on logistics issues, manufacturing firms spending more on supplier failure issues.) With regards to potential change in budget for the next year, $45 \%$ indicated an increase, $41 \%$ no change, and only $14 \%$ indicated a decrease. Companies also indicated that ownership of investments for managing supply chain risks generally resides with Supply Chain/Purchasing (60\%), though in some firms other areas had ownership (Manufacturing/Operations $=12 \%$, Accounting $/$ Finance $=7 \%$, Quality $=6 \%$, Legal $=6 \%, \mathrm{IT}=3 \%$, Logistics $=3 \%$ and Risk $=3 \%$.). Only $17 \%$ of firms had a specific budget to address supply chain issues, with other firms reporting that budget for managing supply chain risks came from other specific department $(57 \%)$ or general operations $(26 \%)$. It seems that while spending intentions for managing supply chain risks are moderate, funding is poorly targeted and ownership is not centered within the SCM discipline. Managing risks is just now reaching the core of traditional and mature SCM applications. Organization: Respondents indicated that they have no intention to outsource risk management. Currently however, the supply chain function lacks the appropriate knowledge and structure (e.g., no supply risk managers linked with corporate risk managers) to most effectively mitigate supply risks. It would appear that the corporate function is involved with risk management but does not necessarily coordinate risk management activities in the whole group.

Table 4. Internal environment and objective setting

\begin{tabular}{lll}
\hline NEED & Mean & Std. Dev. \\
\hline Managing supply chain risk is an increasingly important initiative for our operations. & 5.65 & 1.30 \\
Without a systematic analysis technique to assess risk, much can go wrong in a supply chain. & 5.54 & 1.03 \\
It is critical for us to have an easily understood method to identify \& manage supply chain risk. & 5.30 & 1.23 \\
My workplace plans on evaluating or implementing supply chain risk tools and technologies. & 4.98 & 1.58 \\
We are very concerned about our supply chain resiliency, and the failure implications. & 4.78 & 1.59 \\
APPROACH & & \\
There is no single set of tools or technologies on the market for managing supply chain risks. & 5.24 & 1.49 \\
We are currently using some form of supply chain risk management tools and services. & 4.46 & 1.93 \\
Managing supply chain risks is driven by reactions to failures rather being proactively driven. & 4.39 & 1.36 \\
Proactive risk mitigation efforts applied to the supply chain is common practice for us. & 4.33 & 1.49 \\
Supply chain risk initiatives are driven from the bottom up rather than top down. & 3.67 & 1.56 \\
BUDGET & 4.30 & 1.86 \\
We do plan on investing nontrivial amounts in managing supply chain risks. & 3.91 & 1.94 \\
Funding for managing supply chain risks will come from a general operations budget. & 3.65 & 1.96 \\
We have a dedicated budget for activities associated with managing supply chain risks. & 3.37 & 1.58 \\
Our spending intentions for managing supply chain risks are very high. & & \\
ORGANIZATION & 4.00 & 1.86 \\
I fully understand the activities being performed by our risk management group. & 3.70 & 1.26 \\
Supply chain employees understand government legislation \& geopolitical issues. & 2.53 & 1.74 \\
My workplace uses supply chain risk managers who work closely with corporate risk mgmt. & 2.25 & 1.28 \\
We are planning to outsource all or some of our risk management functions. &
\end{tabular}




\subsubsection{Event Identification and Risk Assessment}

Table 5 suggests that although specific risk issues (e.g., moving facilities overseas) may be carefully evaluated, only about half the firms indicated that a key part of SCM is documenting the likelihood and impact of risks. Further, only half the firms exploit risks to an advantage, This is not surprising given that few firms have an integrated risk strategy and appropriate supply chain risk management skills as previously discussed.

Respondents see a broad set of risk factors that pose a disruption to their supply chains. These risks did not vary much by industry. Supplier failure/reliability, bankruptcies of suppliers, logistics failure, commodity cost volatility, natural disasters, and strikes/labor disputes were the highest rated factors. The non-manufacturing respondents were more inclined to place a higher priority on logistics failure which is not surprising since they were mostly made up of distributors and a retailer. Respondents were also asked if each supply chain risks would increase, stay the same, or decrease in the next 1-2 years. The risks most frequently identified as increasing in the future include: currency exchange, interest, and/or inflation rate fluctuations; commodity cost volatility; bankruptcy, ruin, or default of suppliers, shippers, etc.; and banking regulations / tighter financing conditions

While supplier failure is a high risk factor for all the firms and will increase in risk for several of the firms, 13 firms did say that they expect supplier failure to be less of a risk in the future. A close assessment of these 13 firms reveals that they have done the most to build risk considerations into as many SCM applications as possible.

Some of the top risk factors are to a large extent beyond the control of buying organizations (e.g., natural disasters, default or ruin of supplier, geopolitical events). Managers insisted that while preventing these will not always be possible, reacting to them quickly is an option through contingency planning.

Table 5. Event identification and risk assessment

\begin{tabular}{lll}
\hline Issue & Mean & Std. Dev. \\
\hline Risks of moving manufacturing facilities overseas are carefully evaluated. & 5.65 & 1.15 \\
Supplier reliability and continuous supply is the top risk factor for our supply chain. & 5.35 & 1.34 \\
Risks of not being able to fulfill a spike in consumer demand are carefully evaluated. & 5.22 & 1.25 \\
Key metrics are in place to measure the risk associated with key suppliers. & 4.65 & 1.68 \\
We apply high levels of analytical rigor to assess our supply chain practices. & 4.37 & 1.53 \\
$\begin{array}{l}\text { A key part of our supply chain management is documenting the likelihood \& impact of } \\
\text { risks. }\end{array}$ & 4.20 & 1.67 \\
$\begin{array}{l}\text { We can actually exploit risk to an advantage by taking calculated risks in the supply } \\
\text { chain. }\end{array}$ & 4.02 & 1.63 \\
Taxes such as excise and VAT impact our supply chain decisions. & 3.86 & 1.69 \\
\hline
\end{tabular}

\subsubsection{Risk Response}

Table 6 suggests that companies use a range of response options by accepting, reducing or sharing risks. Inventory management in particular was a critical SCM application used to buffer risk and serve as a de-coupler between echelons of the supply chain when risk was accepted. The table also suggests that although contingency plans may be in place, there will always be some disruptions that ultimately will impact a firm.

Reduction activities focused on the standard SCM practice of identifying qualified suppliers. Very few firms used postponement or product differentiation approaches, somewhat surprising given the discussion of "mass customization" and "portfolio management" over the last decades. Risk sharing appears to be focused on development of strong supplier relationships. Few firms seem to be taking advantage of hedging and speculation approaches, particularly given the recognized volatility of global markets. Even fewer firms seem to be engaged in joint technology development, which is where lifecycle risks might be most effectively addressed.

\subsubsection{Control Activities}

Table 7 suggests that firms are not using training or network optimization tools to ensure risk management practices are properly executed. However, other performance analysis tools (e.g., spend analysis, business process management) seemed to be in place, though it is unclear if such tools are integrated to optimize the entire value chain performance. 
Table 6. Risk response

\begin{tabular}{|c|c|c|}
\hline Item & Mean & Std. Dev. \\
\hline \multicolumn{3}{|l|}{ ACCEPTANCE } \\
\hline Inventory management (buffers, safety stock levels, optimal order/production qty.) & 4.96 & 1.69 \\
\hline $\begin{array}{l}\text { We have placed an increased focus on inventory management to deal with supply } \\
\text { risks. }\end{array}$ & 4.80 & 1.34 \\
\hline $\begin{array}{l}\text { Our suppliers are required to have secure sourcing, business continuity, \& } \\
\text { contingency plans. }\end{array}$ & 4.62 & 1.71 \\
\hline Contingency Planning (jointly with suppliers) & 4.22 & 1.25 \\
\hline $\begin{array}{l}\text { We are prepared to minimize the effects of disruptions (terrorism, weather, theft, } \\
\text { etc.) }\end{array}$ & 3.70 & 1.31 \\
\hline \multicolumn{3}{|l|}{ REDUCTION } \\
\hline Using an approved list of suppliers & 5.78 & 1.18 \\
\hline Multiple sourcing (rather than sole sourcing) & 4.04 & 1.36 \\
\hline Increasing product differentiation & 3.91 & 1.50 \\
\hline Postponement (delaying the actual commitment of resources to maintain flexibility) & 3.70 & 1.35 \\
\hline \multicolumn{3}{|l|}{ SHARING } \\
\hline Partnership formation and long-term agreements & 5.11 & 1.08 \\
\hline Supplier development initiatives & 4.83 & 1.37 \\
\hline Speculation (forward placement of inventory, forward buying of raw material, etc.) & 4.07 & 1.69 \\
\hline We are hedging our raw materials exposure to reduce input cost volatility. & 3.78 & 1.49 \\
\hline Hedging strategies (to protect against commodity price swings) & 3.61 & 1.63 \\
\hline Joint technology development initiatives & 3.59 & 1.47 \\
\hline \multicolumn{3}{|l|}{ Table 7. Control activities } \\
\hline Item & Mean & Std. Dev. \\
\hline Spend management and analysis & 4.85 & 1.53 \\
\hline Inventory optimization tools & 4.78 & 1.66 \\
\hline Business process management & 4.65 & 1.37 \\
\hline Credit and financial data analysis & 4.54 & 1.60 \\
\hline Contract mgmt (e.g., leverage tools to monitor performance against commitments) & 4.48 & 1.64 \\
\hline $\begin{array}{l}\text { We use network design and optimization tools to cope with uncertainty in the supply } \\
\text { chain. }\end{array}$ & 3.66 & 1.85 \\
\hline Training programs & 3.54 & 1.59 \\
\hline
\end{tabular}

4.2.5 Information \& Communications

Table 8 suggests that information systems and communications channels are relatively well established to support supply activities. However, overall visibility is only modest and supply chain risk information accuracy and availability is less than optimal. The information that is communicated can certainly help manage risks, but without communication of risk factors overall ERM effectiveness may be limited.

Most firms in this study did not use their information technology to evaluate their supply chain networks and risks. A few firms did leverage their technology to periodically assess strategic decisions about where to locate distribution centers and manufacturing capacity, and to determine how to service customer demand at the lowest cost and risk. None of them however were using network-design tools in innovative ways such as modeling risks or modeling the networks of their key competitors to test various scenarios and to perform "what-if" analysis. 
Table 8 . Information and communication

\begin{tabular}{lcc}
\hline Item & Mean & Std. Dev. \\
\hline Information gathering & 5.67 & 1.21 \\
Establishing good communications with suppliers & 5.65 & 1.04 \\
Our company uses real-time inventory information and analytics in managing the & 4.76 & 1.52 \\
supply chain. & & \\
Forecasting techniques (e.g., to pre-build \& carry additional inventory of critical & 4.61 & 1.57 \\
items) & & \\
Visibility (detailed knowledge of what goes on in other parts of the supply chain - e.g., & 4.26 & 1.29 \\
finished goods inventory, material inventory, WIP, pipeline inventory, actual demands & & \\
and forecasts, production plans, capacity, yields, and order status) & 4.09 & 1.76 \\
Data warehousing & 3.87 & 1.57 \\
Supply chain risk information is accurate and readily available to key-decision makers. & 3.42 & 1.85 \\
Demand signal repositories & 3.25 & 1.94 \\
Network design analysis programs & & \\
\hline
\end{tabular}

4.2.6 Monitoring

Table 9 indicates that firms are monitoring supply chain performance using traditional processes (e.g., supplier visits and assessment systems) but relatively few assess their risk management processes relative to best in class. Table 10 suggests that most firms are relatively satisfied with key SCM performance outcomes. However, $65 \%$ of the respondents indicated that they have had supply disruptions that have caused financial hardships in the past 24 months.

Table 9. Monitoring

\begin{tabular}{lcc}
\hline Item & Mean & Std. Dev. \\
\hline Supplier performance measurement systems & 5.35 & 1.61 \\
Visiting supplier operations & 5.04 & 1.32 \\
Consistent monitoring and auditing of a supplier's processes & 4.59 & 1.72 \\
Benchmarking (internal, external, industry-wide, etc.) & 4.59 & 1.54 \\
We have placed an emphasis on incident reporting to decrease the effects of & 4.50 & 1.43 \\
disruptions. & & \\
We actively benchmark our supply chain risk processes against competitors. & 3.57 & 1.68 \\
\hline Table 10. Satisfaction with performance & & \\
\hline Item & Mean & Std. Dev \\
\hline Damage-free and defect-free delivery & 5.41 & 0.83 \\
Meeting customer service levels & 5.07 & 1.20 \\
Logistics and delivery reliability & 4.96 & 1.01 \\
Order completeness and correctness & 4.96 & 1.11 \\
Supplier reliability and continuous supply & 4.85 & 0.99 \\
Reduced disruptions in the supply chain & 4.59 & 1.15 \\
After sales service performance & 4.57 & 1.29 \\
Inventory management & 4.52 & 1.22 \\
Lower commodity prices & 3.98 & 1.27 \\
Reduced material price volatility & 3.80 & 1.51 \\
\hline
\end{tabular}




\section{Discussion}

Risk management professionals and organizations, including COSO, indicate that risk management is led by senior management, and that ERM is a continuous process embedded throughout the organization's culture, strategy and processes, and that is integrated across all levels of the firm. ERM translates strategy into tactical and operational objectives, assigning ownership throughout the organization with each manager and employee responsible for the management of risk as part of their job description. It supports accountability, performance metrics and rewards, promoting operational efficiency at all levels including SCM. However, most of the supply risk management strategies in this study appear to be fragmented (e.g., one group buys insurance, another administers claims, another handles everything related to safety or security, another selects dual sources, etc.)

SCM focuses primarily on the input part of the value chain, though it has at least some type of support role throughout the value chain. A closely aligned strategy and relationship between risk managers and others in the organization supports effective supply chain risk management. A corporate risk management group can address risks for the entire supply chain and life cycle of a program. There has been an increased recognition of the "Chief Risk Officer" position to take on such responsibilities. Though not an absolute requirement, having somebody in charge of ERM enables integrated risk management. The supply chain risk manager would work closely with corporate risk management, as well as with the supply chain managers. In this study, a gap was suggested as firms failed to use supply chain managers who work closely with corporate risk management, and managers did not fully understand the activities being performed by their risk management groups.

Gaining management support may be the most challenging part of implementing a proactive system for managing risks in the supply chain. SCM leaders might emphasize the importance of supply chain risk management to senior management in order to get the properly targeted resources necessary to implement such a system, rather than the poorly targeted budgets seen in this study. The firms in this study recognized the need for risk management and had at least moderate top management support for such initiatives. This suggests the strong potential for proactive risk management, yet few firms seem to have such an approach.

Managers agreed that without a systematic analysis technique to assess risk, much can go wrong in a supply chain (i.e., unexpected cost, extended lead times, poor quality, or numerous other negative performance variables). Analyzing the risk associated with SCM is a relatively new subject, and little has been done to assist managers with this process. It would seem a key first step is documenting and analyzing risk. The method for analyzing supply chain risk should be a cross-functional process that involves senior management as well as key stakeholders from finance, operations, internal audit, and risk management. This could make roles unclear, so responsibilities need to be defined. The companies in this study generally have not adopted such boundary spanning processes for risk management. Instead, they have managed risks within functional silos.

In the absence of cross functional processes and lacking risk management applications, the supply chain managers in this study are building risk considerations into existing traditional SCM applications (e.g., spend, contract, \& inventory management, demand planning, benchmarking, etc.). This study suggests that supply chain managers generally coordinate the work to maintain an optimal balance between risk exposures and costs for damages versus protection activities.

Supply chain risk management goes beyond documenting the likelihood and impact of risks. It also provides visibility to risks when they occur and translates that risk information to key decision makers so that they can evaluate and act on information. This study suggests that throughout the supply chain, key operational data and information such as inventory, demand, forecasts, production and shipment plans, work in progress, yields, capacities and backlogs was accessible to key members of the supply chains. However, this study also showed that documenting the likelihood and impact of risks was not always a key part of SCM and that supply chain risk information was not readily available to key decision makers. Perhaps because of this risk information shortcoming, very few of the firms were able to exploit risk to an advantage by taking calculated risks in the supply chain and even fewer were prepared to minimize the effects of disruptions. Thus, it is important that data and information are tightly managed and that any updates are made as timely as possible. The accuracy of the data should be a source of confidence to the parties using the data.

The role of supply network design and optimizations tools for risk management is still evolving on the SCM side. Some of the firms in this study make use of network design tools for infrequent, long-range decision making, such as manufacturing location or distribution capacity given long-term demand expectations. However, there was no indication that there are new cases of usage, such as helping companies understand, model, and cope with increasing levels of uncertainty in the supply chain or network. Some companies have adopted software tools to address 
multi-echelon inventory optimization. Firms are using these tools to apply probabilistic forecasting techniques to make inventory policy and configuration decisions and to evaluate different inventory strategies, though none of them used it to evaluate postponement strategies. Used effectively, they can help companies improve customer-service levels and fill rates, dampen the impact of supply disruptions, reduce risk, and yield better trade-off decisions between customer-service levels and required inventory investment.

All of the firms in this study have developed and monitor a set of performance metrics to maintain a risk profile for their supply chains. They do so by using an assortment of tools and techniques such as: initial supplier evaluations, QS audits, industry benchmarking, supplier questionnaires, report cards, capacity planning, lead-time analysis, financial risk assessment, business continuity plans, risk analysis based on accounts payable performance, historical data, technical capability assessment, on-site capability reviews, forecasting techniques and analysis, data tracking with customers to identify demand trends, supplier performance measurement, etc. Some also used supplier risk rankings, similar to credit scores used in the financial industry, to measure suppliers on stability, contingency planning, and on-target delivery performance. Firms tracked this type of performance through supplier scorecards to monitor leading indicators that impact risk. However, no firm had an ongoing risk-review process to ensure that they keep their risk profile within an optimal range of economic impact. In general, the development of proactive risk management performance metrics in the supply chain was lacking in this study. The supplier scorecards were not balanced, optimal, and supported reactive decision making.

Several of the firms used financial reports and questionnaires during supplier approval to compare supply candidates to the business requirements of the buyers or project teams. When justified by a perceived level of risk, a few of the firms went one step further and had candidate comparison matrices (e.g., supplier profiling form and supply chain PFMEA). Additionally, most had formal processes for supplier visits (e.g., rapid plant assessment, site verification of the supplier questionnaire, etc.). Some firms used life cycle management with supplier report cards and their buyers would conduct periodic supply chain reviews. In one firm, sourcing was assigned risk ownership and they used PFMEA principles to evaluate risk impact. For each risk, they would assess what the financial impact would be in the event of a disruption. They then assigned a probability to each risk area and then they prioritized by multiplying the financial impact by the risk probability.

This study also demonstrates that the measurement of risk factors does not necessarily require a new or unique set of performance measures. For example, one firm used average on-time delivery as a measure of supplier performance and chose to look more closely at the peaks and valleys of this indicator to determine the supplier's risk impact on its own delivery performance. In another example, key metrics were established to measure the risk associated with key suppliers and their performance against service level agreements. Supplier agreements were then aligned with the established levels negotiated with the company's key customer agreements.

Firms face a variety of risks and are unlikely to be able to cost effectively identify and respond to all risks. Some firms conducted a Pareto analysis to determine where to focus their SCM risk management efforts. The most common current risk identified by respondents was supplier failure. Though some firms indicated that in the future such risk will decrease, more firms indicated that the risk will increase. This provides support for the suggestion that current ad-hoc approaches by the firm and SCM are largely ineffective in the long term.

Commodity cost volatility was also a growing concern, but with limited amounts of systems to manage its risk. For example, the majority of the firms strongly disagreed that they were using hedging strategies (to protect against commodity price swings) and speculation (forward placement of inventory, forward buying of raw material, etc.) for managing supply chain risks (and yet it was identified as one the top risk factors). Not surprisingly, firms were very disappointed with their supply chain's performance on lower commodity prices and reduced material price volatility. Only one firm in the sample had a system in place to proactively manage commodity prices. This firm had a dedicated staff that used a price sliding system on key commodities which were tied to market indices (e.g., plastics, metals, rubbers, etc.).

Some firms in this study used management scorecards (e.g., dashboards, reviews, audits, etc.) to identify trends in advance and to view the progress of their supply chains according to a collection of performance indicators. In this manner, they do get some early warning signs if suppliers or carriers are underperforming. However, they fall short on having systems with event-based alerts that let them know when their supply chains are at risk. Until that happens, it will be difficult for managers to take appropriate and well managed risks. Instead, they may outsource to low cost regions to meet their cost savings goals and not stay within an optimal range on the risk management side.

In general, no one was compensated or incented in their day to day job to look at and evaluate the risks within an optimal range of economic impact. For example, a typical off-shore target for several supply chain managers was to 
achieve " $x$ " million dollars of component off-shore in " $y$ " years. Such situations may force managers to compromise on risk issues as they focused on achieving cost efficiency. If the reward system only rewards those who achieve their objectives irrespective of due attention to risks, then managers will strive to achieve objectives at the cost of disproportionate risks. In most of the firms in this study, the major objectives were to reduce inventory, improve in-stock availability, and cut costs. Most of these firms had specific targets for off-shore sourcing that that forced managers to inevitably compromise on risk issues. Managing risks in the supply chain was perceived as something that contradicts the process of achieving other company objectives.

Responses to supply risk included acceptance, reduction and sharing. Though firms used a variety of techniques, unfortunately this research did not determine if the techniques were used based on sound risk management principles or because it was the only technique the firm was able to implement. Perhaps the old adage that "if the only tool you have is a hammer, then everything looks like a nail" applies to supply risk management.

\section{Conclusion}

This descriptive research examined existing supply chain risk management (SCRM) strategies, processes and frameworks to determine how well they align and integrate with enterprise risk management (ERM) systems. It is suggested that the ERM framework proposed by The Committee of Sponsoring Organizations (COSO) of the Treadway Commission (COSO, 2004) provides a reasonable framework that enables firms to accomplish integration of SCRM and ERM. Such integration of SCRM with ERM frameworks may provide a more solid foundation for future research through the use of consistent terms, measures, contexts and interrelationships. Such integration might also enable supply managers to more efficiently and effectively develop SCRM strategies, secure the necessary resources, and execute SCRM at their firms.

\section{References}

Armstrong, J.S., Overton T.S. (1977). Estimating Nonresponse Bias in Mail Surveys. Journal of Marketing Research 14(3): 396-402. http://dx.doi.org/10.2307/3150783

Ballou, B., Heitger D. (2005). A Building Block Approach for Implementing Coso's Enterprise Risk Management Integrated Framework. Management Accounting Quarterly 6(2): 1-10.

Beasley, M., Clune R., Hermanson D. (2005). Erm: A Status Report. The Internal Auditor 62(1): 67-72.

Black, S., Porter L. (1996). Identification of the Critical Factors of Tqm. Decision Sciences Journal 27(1): 1-21. http://dx.doi.org/10.1111/j.1540-5915.1996.tb00841.x

Blackhurst, J., Wu T., O'Grady P. (2005). Pdcm: A Decision Support Modeling Methodology for Supply Chain, Product and Process Design Decisions. Journal of Operations Management 23(3-4): 325-343. http://dx.doi.org/10.1016/j.jom.2004.05.009

Bowling, D., Rieger L. (2005). Making Sense of Coso's New Framework for Enterprise Risk Management. Bank Accounting \& Finance Feb/Mar: 35-40.

Capon, N., Kaye M., Wood M. (1994). Measuring the Success of a Tqm Programme. International Journal of Quality and Reliability Management 12(8): 8-22. http://dx.doi.org/10.1108/02656719510097471

Chapman, C. (2003). Bringing Erm into Focus. The Internal Auditor 60(3): 30-35.

Chiang, C.Y., Kocabasoglu-Hillmer C., Suresh N. (2012). An Empirical Investigation of the Impact of Strategic Sourcing and Flexibility on Firms Supply Chain Agility. International Journal of Operations and Production Management 32(1): 49-78. http://dx.doi.org/10.1108/01443571211195736

COSO. (2004). Enterprise Risk Management - Integrated Framework. Committee of Sponsoring Organizations of the Treadway Commission.

COSO. (2010). Current State of Enterprise Risk Oversight and Market Perceptions of Coso's Erm Framework. Committee of Sponsoring Organizations of the Treadway Commission.

Curkovic, S., Melnyk S., Calantone R., Handfield R. (2000). Validating the Malcolm Baldrige National Quality Framework through Structural Equation Modeling. International Journal of Production Research 38(4): 765-791. http://dx.doi.org/10.1080/002075400189149

Dean, J., Bowen D. (1994). Management Theory and Total Quality: Improving Research and Practice through Theory Development. Academy of Management Journal 19(3): 392-418. 
Eisenhardt, K. (1989). Building Theories from Case Study Research. The Academy of Management Review 14(4): $532-550$

Flynn, B., Schroeder R., Sakakibara S. (1994). A Framework for Quality Management Research and an Associated Instrument. Journal of Operations Management 11(4): 339-366. http://dx.doi.org/10.1016/S0272-6963(97)90004-8

Giannakis, M., Louis M. (2001). A Multi-Agen Based Framework for Supply Chain Risk Management Journal of Purchasing and Supply Management 17(1): 23-31.

Hallikas, J., Karvonen I., Pulkkinen U., Virolainen V.M., Tuominem M. (2004). Risk Management Processes in Supplier Networks. International Journal of Production Economics 90(1): 47-58. http://dx.doi.org/10.1016/j.jpe.2004.02.007

Holschbach, E., Hofmann E. (2011). Exploring Quality Management for Business Services from a Buyer's Perspective Using Multiple Case Study Evidence. International Journal of Operations \& Production Management 31(6): 648-685. http://dx.doi.org/10.1108/01443571111131980

Hoyt, R., Liebenberg A. (2011). The Value of Enterprise Risk Management. Journal of Risk and Insurance 78(4): 795-822. http://dx.doi.org/10.1111/j.1539-6975.2011.01413.x

Inderfurth, K., Kelle P. (2011). Capacity Reservation under Spot Market Price Uncertainty. International Journal of Production Economics 133(1): 272-279. http://dx.doi.org/10.1016/j.ijpe.2010.04.022

Kern, D., Moser R., Hartmann E., Moder M. (2012). Supply Risk Management: Model Development and Empirical Analysis. International Journal of Physical Distribution \& Logistics Management 42(1): 60-82. http://dx.doi.org/10.1108/09600031211202472

Khan, O., Burnes B. (2007). Risk and Supply Chain Management: A Research Agenda. The International Journal of Logistics Management 18(2): 197-216. http://dx.doi.org/10.1108/09574090710816931

Kleindorfer, P.R., Saad G.H. (2005). Managing Disruptions in Supply Chains. Production and Operations Management 14(1): 53-68. http://dx.doi.org/10.1111/j.1937-5956.2005.tb00009.x

Kumar, S., Verruso J. (2008). Risk Assessment of the Security of Inbound Containers at Us Ports: A Failure, Mode, Effects, and Criticality Analysis Approach. Transportation Journal 47(4): 26-41.

Laeequddin, M., Sardana G.D., Sahay B.S., Abdul Waheed K., Sahay V. (2009). Supply Chain Partners Trust Building Process through Risk Evaluation: The Perspectives of Uae Packaged Food Industry. Supply Chain Management 14(4): 280-290. http://dx.doi.org/10.1108/13598540910970117

Landsittel, D., Rittenberg L. (2010). Coso: Working with the Academic Community. Accounting Horizons 24(3): 455-469. http://dx.doi.org/10.2308/acch.2010.24.3.455

Liu, Z., Cruz J. (2012). Supply Chain Networks with Corporate Financial Risks and Trade Credits under Economic Uncertainty. International Journal of Production Economics 137(1): 55-67. http://dx.doi.org/10.1016/j.jpe.2012.01.012

Manuj, I., Mentzer J.T. (2008). Global Supply Chain Risk Management. Journal of Business Logistics 29(1): 133-156. http://dx.doi.org/10.1002/j.2158-1592.2008.tb00072.x

Martin, C., Mena C., Khan O., Yurt O. (2011). Approaches to Managing Global Sourcing Risk. Supply Chain Management 16(2): 67-81. http://dx.doi.org/10.1108/13598541111115338

Matook, S., Lasch R., Tamaschke R.." 29.3 (2009). 241-67. 2009. Supplier Development with Benchmarking as Part of a Comprehensive Supplier Risk Management Framework. International Journal of Operations and Production Management 29(3): 241-267. http://dx.doi.org/10.1108/01443570910938989

Miles, M., Huberman A. (1994). Qualitative Data Analysis: A Sourcebook of New Methods. Newbury Park, CA: Sage Publications.

Nocco, B., Stulz R. (2006). Enterprise Risk Management: Theory and Practice. Journal of Applied Corporate Finance 18(4): 8-20. http://dx.doi.org/10.1111/j.1745-6622.2006.00106.x

Samad-Khan, A. (2005). Why Coso Is Flawed. Operational Risk 6(1): 24-28.

Saraph, V., Benson P., Schroeder R. (1989). An Instrument for Measuring the Critical Factors of Quality Management. Decision Sciences 20(4): 810-829. http://dx.doi.org/10.1111/j.1540-5915.1989.tb01421.x 
Smithson, C., Simkins B. (2005). Does Risk Management Add Value? A Survey of the Evidence. Journal of Applied Corporate Finance 17(3): 8-17. http://dx.doi.org/10.1111/j.1745-6622.2005.00042.x

Sobel, P. (2006). Building on Section 404: Investments in Sarbanes-Oxley Compliance Can Provide a Solid Foundation for Enterprise Risk Management Projects. The Internal Auditor 63(2): 38-44.

Sodhi, M.S., Son B.G., Tang C.S. (2012). Researcher's Perspective on Supply Risk Management. Productions and Operations Management 21(1): 1-13. http://dx.doi.org/10.1111/j.1937-5956.2011.01251.x

Tang, C.S. (2006). Perspectives in Supply Chain Risk Management. International Journal of Production Economics 103(2): 451-488. http://dx.doi.org/10.1016/j.ijpe.2005.12.006

Tummala, R., Schoenherr T. (2011). Assessing and Managing Risks Using the Supply Chain Risk Management Process (Scrmp). Supply Chain Management 16(6): 474-483. http://dx.doi.org/10.1108/13598541111171165

Zsidisin, G., Ellram L., Carter J., Cavinato J. (2004). An Analysis of Supply Risk Assessment Techniques. International Journal of Physical Distribution \& Logistics Management 34(5): 397-413. http://dx.doi.org/10.1108/09600030410545445

Zsidisin, G., Hartley J. (2012). A Strategy for Managing Commodity Price Risk. Supply Chain Management Review $\operatorname{Mar} / \operatorname{Apr}(2): 46-53$.

Zsidisin, G., Wagner S. (2010). Do Perceptions Become Reality? The Moderating Role of Supply Chain Resiliency on Disruption Occurence Journal of Business Logistics 31(2): 1-20. 